Tyndale Bulletin 70.2 (2019) 221-243

\title{
NEGOTIATING HOSTILITY THROUGH BENEFICIAL DEEDS
}

\author{
Sean du Toit \\ (sean@acnz.ac.nz)
}

\begin{abstract}
Summary
In this article we have surveyed the concept of $\dot{\alpha} \gamma \alpha \theta 0 \pi \circ \varepsilon \dot{\varepsilon} \omega$. It has been argued that this refers to various kinds of beneficial deeds, either for a community or individuals. At times the purpose of these good works is to neutralise hostility and convert an enemy into a friend. This strategy of benefiting an enemy is seen in both Graeco-Roman, Jewish, and early Christian writings. This provides an important context within which to understand and interpret 1 Peter. Contrary to Travis Williams' proposal, good works are not to be understood as exclusively Jewish and Christian practices that were used to subvert hegemonic power structures within the Graeco-Roman world. Rather, in keeping with the educational concerns of early Christianity, what we see in 1 Peter is an effort to communicate clearly to a Gentile audience using familiar topoi. The purpose of benefitting others, including outsiders, is to provide an opportunity to allay pagan concerns that these Christians were a dangerous community. Peter's strategy is that by demonstrating that Christians were people who benefit others, the hope is that this will both alleviate ignorance and provide an opportunity for ethical witness.
\end{abstract}

\section{Introduction}

The concept of $\dot{\alpha} \gamma \alpha \theta$ o $\pi$ oté $\omega$ (and cognates) is significant in 1 Peter $(2: 12,14,15,20 ; 3: 6,11,13,17 ; 4: 19)$. In what follows we seek to argue that Peter has employed this concept as a key element in his strategy for how the audience should negotiate life in the Graeco-Roman world. The consensus of earlier scholarship has been that references to 'good 
works' refer to a variety of activities that were commended by GraecoRoman standards. ${ }^{1}$ However, Williams notes that the consensus view has not provided a clear proposal regarding how good works can alleviate the hostility faced by the audience. In his view, there is therefore a disconnection between problem and solution. ${ }^{2}$ I wish to address this problem and propose that 'good works' were seen as a solution to social hostility and conflict. There are two related issues that must occupy our attention. Firstly, we must investigate the referent of good works in the ancient world. Secondly, we must ascertain the purpose of good works. I shall argue that Peter's conception of 'good works' refers to beneficial deeds, which do overlap in significant areas with Graeco-Roman concepts of good works. To do this, we survey material in Graeco-Roman sources, which describe how 'good works' were appealed to as a strategy to negotiate conflict. This is followed by a discussion of the content of 'good works'. I then conclude with a discussion of how the concept of 'beneficial deeds' fits within Peter's strategy.

\section{The Content of Beneficial Deeds}

LSJM offers the gloss 'good, blessing, benefit' ${ }^{3}$ for $\tau$ ò $\alpha$ $\gamma \alpha \theta$ óv. 4

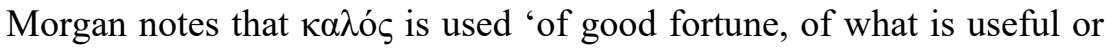
profitable for an individual and of something that is good for society at large'. ${ }^{5}$ At times the two are joined together to form $\kappa \alpha \lambda$ ó $\varsigma \alpha \dot{\gamma} \gamma \alpha \theta$ ó.$^{6}$ Williams argues, broadly speaking, that there are two specific referents to the concept of 'good works' in Graeco-Roman literature. These are civic benefaction and moral excellence. ${ }^{7}$ Civic benefaction was

1 See Travis B. Williams, Good Works in 1 Peter: Negotiating Social Conflict and Christian Identity in the Greco-Roman World (Tübingen: Mohr Siebeck, 2014): 3-9.

2 Williams, Good Works in 1 Peter, 10-11.

3 LSJM \#199 - from Henry George Liddell, Robert Scott, and Henry Stuart Jones, $A$ Greek-English Lexicon (9th ed. with revised supplement; Oxford: Clarendon, 1996).

4 See also LSJM \#198, where it can be understood as beneficence.

5 Teresa Morgan, Popular Morality in the Early Roman Empire (New York: Cambridge University Press, 2008): 192.

6 See John H. Elliott, 1 Peter: A New Translation with Introduction and Commentary (vol. 37B, Anchor Yale Bible; New Haven and London: Yale University Press, 2008): 166-78

7 Williams, Good Works in 1 Peter, 39-67. 
pervasive in the Graeco-Roman world. ${ }^{8}$ While some have seen the dominant referent of 'doing good' as civic benefaction, others like Betz note that $\tau$ ò $\kappa \alpha \lambda o ́ v$ and $\tau$ ò $\alpha \gamma \alpha \theta$ óv reflect language that comes from Hellenistic moral philosophy and suggest that these two terms reflect essentially the same meaning. ${ }^{9}$ Williams never explains why Peter could not have adopted his language about 'good works' from GraecoRoman moral philosophy. This is especially surprising because he states that 'Similar language came to be employed within the framework of Hellenistic moral philosophy as a reference to the quality and character of one's life, apart from the necessary precondition of material wealth.' ${ }^{10}$ With regards to 'doing good', what civic benefaction and moral philosophy have in common is that both of them refer to deeds that benefit either a group of people or an individual. The common denominator is activity that benefits another. This explains the various descriptions provided by our lexicons and makes sense of the historical usage of these terms to refer to both civic benefaction and virtuous behaviour.

This concept of doing what is beneficial to others is prevalent in the ancient world and is considered a virtue. ${ }^{11}$ In recounting a story of Socrates and his associates who are discussing the law and whether or

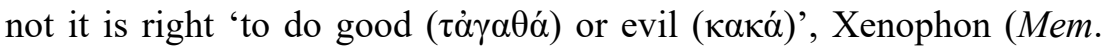
1.2.42) tells us that Socrates and his associates were aiming to help

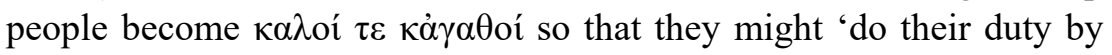
house and household, and relatives and friends, and city and citizens' (Mem. 1.2.48). An example of such duty within the household is doing good to one's parents (Mem.2.2.13) by taking care of them. An aspect of doing good is thus portrayed as the discharge of virtuous duty in beneficial actions of those in a household, and among interpersonal

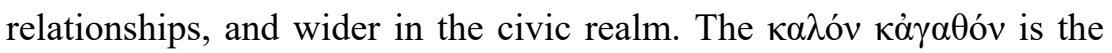
one who embodies virtues such as $\sigma \omega \varphi \rho o v \varepsilon \dot{\varepsilon} \omega$ (Mem. 1.2:17-18). These duties benefit the harmony and flourishing of households and thus ultimately the city.

8 For inscriptions and literary evidence see Bruce Winter, 'The Public Honouring of Christian Benefactors: Romans 13.3-4 and 1 Peter 2.14-15', JSNT 34 (1988): 87-92. For another survey see Williams, Good Works in 1 Peter, 68-81 and 280-95.

9 So Willem Cornelius van Unnik, A Classical Parallel to 1 Peter ii. 14 and 20 (Sparsa Collecta vol. 2; Supplements to Novum Testamentum vol. 30; Leiden: Brill,

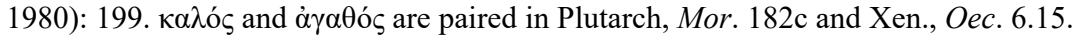

10 Williams, Good Works in 1 Peter, 66.

11 See Mus. Ruf. 14; Marc. Aur. 1.15.3; Philo, Spec. Laws 4.58. 
In a discussion on the redundancy of expensive clothes and houses, Musonius Rufus argues through a series of rhetorical questions that luxury is mostly unnecessary and 'many people might have benefited by public and private charity' had these funds not been used on luxury.

How much more commendable than living a life of luxury it is to help many people. How much nobler than spending money for sticks and stones to spend it on men. How much more profitable than surrounding oneself with a great house to make many friends, the natural result of cheerfully doing good. What would one gain from a large and beautiful house comparable to what he would gain by conferring the benefits of his wealth upon the city and his fellow-citizens? ${ }^{12}$

Musonius argues that doing good is better for oneself and others than the accumulation of luxurious clothes and accommodation. Lest we think only those with money are able to benefit others, we have the example of a doctor using his skills as a benefit to others. ${ }^{13}$ Thus we see that both wealth and skills could be used to benefit others, and such activity is understood as doing good.

This leads us to Seneca's discussion of benefaction and slaves. The question was raised as to "whether a slave can confer a benefit on his master'. ${ }^{14}$ Seneca argues that a slave can benefit a master through virtuous actions such as loyalty. This is because Seneca defines a benefit as 'the opportunity of being useful' (On Benefits 1.7.1) or a 'Benefit is something that does good' (5.12.3). ${ }^{15}$ According to Seneca, the word beneficium includes the idea of 'having done good to' another (5.10.3). Thus when a slave goes beyond what is required and enters into the domain of the free act, then it is considered a benefit. 'Whatever goes beyond the standard benchmark of servile responsibilities, whatever is given not on command but voluntarily, that is a benefit - provided that it is significant enough that it would be termed a benefit if someone else gave it.' ${ }^{16}$ The obligation to return a benefit gratefully extends even to so-called enemies. ${ }^{17}$ Seneca's treatment of 'benefits' or 'favours' is important because it provides another window on to contemporary thinking at the time of 1 Peter

Mus. Ruf. 19.25-30.

13 IG V 1145. Provenance: Gytheion. Honorand: Damadius. 86 BC. See also Sirach $38: 1$.

14 See the discussion in Ben. 3.18-21.

15 See also 5.10.1, 'A benefit is the offering of something so as to be useful.'

16 Ben. 3.21.

17 Ben. 2.18.3; 3.12.3. 
regarding benefaction. Poh offers the following examples of benefaction from Seneca:

$[\mathrm{H}]$ elping someone with money, paying for someone else's debt, giving land in order that by its fertility the price of grain may be lowered, giving a loaf of bread in a time of famine, pointing out a spring of water to a thirsty man, giving useful advice and sound precept, helping someone with influence, protecting someone's reputation, preserving his life and liberty, attending to one who is sick, defending someone when he is on trial for his life. ${ }^{18}$

From what we have written in 1 Peter, these examples could, without extenuating nuances, be validated by our author as examples of beneficial deeds. They provide a helpful window into real life situations where Christians could be of benefit to others. Williams provides further examples of those who benefit their community such as judges who help resolve conflicts or athletes who win at the games and thus benefit the honour of their city, and they are also described as $\kappa \alpha \lambda o ́ \varsigma \kappa a ̉ \gamma \alpha \theta$ ós. ${ }^{19}$ "Across a range of Greco-Roman literature, "doing good" consistently refers to the praiseworthy efforts of those who confer some type of benefit(s) upon others. Some of the more common beneficiaries of this good are said to be friends and family.' ${ }^{20}$ Thus there is no need to understand $\dot{\alpha} \gamma \alpha \theta$ o $\pi$ oเé $\omega$ exclusively within the framework of civic benefaction when the evidence suggests it refers to beneficial deeds done either for a group or an individual. ${ }^{21}$ The concept of doing good was understood as more than sharing wealth, but included using one's skills or service to bring about a benefit for others. Such beneficial deeds are not reserved for the wealthy or free but can also be located in the virtuous activities of slaves and others under authority.

18 Chu Luan Poh, 'The Social World of 1 Peter' (Ph.D. dissertation, King's College London, University of London, 1998): 104. See Seneca, Ben. 1.2.4-5; 2.35.3; 3.8.2-3; 3.9.2-3.

19 Williams, Good Works in 1 Peter, 42-43.

20 Williams, Good Works in 1 Peter, 61. See Dionysius Halicarnassus, Ant. Rom. 3.11.9; 8.29.1; 19.16.1; Plutarch, Mor. 90F; Lucian, Nav. 44; Alexander Numenius, De Fig. 2 $\alpha$; Porphyry, Abst. 4.22.

21 Thus Williams, Good Works in 1 Peter, 103 is wrong to state that 'euergetism would be the most natural context in which the terms would be understood'. Moral philosophy provides an equally plausible context for this concept. Furthermore, the category of 'beneficial deeds' explains how this can refer to both euergetism and moral philosophy, since both of them provide a benefit to others. 


\section{The Purpose of Beneficial Deeds}

We must now investigate the purpose of such good works. It seems self-evident from ancient writers that having friends is better than having enemies. The question thus becomes how one wins a friend, and especially one who is an enemy. In Aesop's Fables we are told that 'Many people will not hesitate to confer a benefit on their enemies for the sake of gain' (Fab. 3). The philosopher Diogenes Laertius (third century CE) states 'It is right to confer benefits ( in order to bind him closer to us, and on an enemy in order to make a friend of him' (Vit. Phil. 1.91). These statements illustrate a strategy for dealing with hostility and conflict in the ancient world. ${ }^{22}$ In what follows we shall discuss three moral philosophers from around the first century that also advocate a positive strategy for dealing with social conflict and hostility, namely Epictetus and Plutarch.

The Stoic philosopher Epictetus offers instruction on how to act towards one's enemies in his Encheiridion and his Discourses. Epictetus instructs treating an abuser with gentleness (Ench. 42) as a means of neutralising conflict. 'So when you start out from these considerations, you will be gentle with the man who abuses ( $\tau$ óv

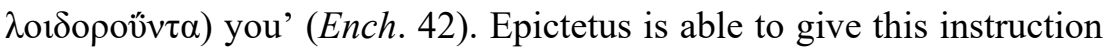
because he reasons that the perpetrator performed such abuse because he has reasoned incorrectly. ${ }^{23}$ In another passage Epictetus suggests one should be more than just gentle with an abuser:

For this too is a very pleasant strand woven into the Cynic's pattern of life; he must needs be flogged like an ass, and while he is being flogged he must love the men who flog him, as though he were the father or brother of them all. (Diss. 3.22.54)

We are not told what the goal of such love is, but we are told that the appropriate response to one's enemies is to love. Perhaps this is because Epictetus views hostility and abuse as an occasion for moral coaching of one's own character (Diss. 3.20.9). This allows one training in patience, dispassionateness, and gentleness. In fact, the best response to hostility is to completely disregard it without it having any

22 See also Stobaeus 4.27.20; Ps. Clement, Hom. 12.26; Polyaenus, Strat. 5.12.

23 Epictetus, Ench. 42, 'When someone does you wrong or speaks ill of you, remember that he does or says so because he thinks that it is his duty. Therefore it is impossible that he acts on what appears to you, but he must act on what appears to himself; accordingly, if his opinion is wrong, the man who has been deceived is the one who suffers the harm.' 
effect on oneself (Diss. 3.13.11,13). Epictetus uses the example of a stone to illustrate how one should respond to abuse (Diss. 1.25.29). A stone is unaffected by abuse, and so too should the Cynic be unmoved by external abuse.

Plutarch provides an insightful window into carefully negotiating hostility. He devotes much space to the issue in a treatise: How to Profit by One's Enemies. ${ }^{24}$ His response is worth quoting in full as it provides a sophisticated and illuminating strategy. He begins by posing the question 'How shall I defend myself against my enemy?'

\begin{abstract}
'By proving yourself good and honourable.' Men are much distressed when they see their enemies' horses winning renown or their dogs gaining approval. At the sight of a well-tilled field or a flourishing garden they groan. What, think you, would be their state of mind if you were to show yourself to be an honest, sensible man and a useful citizen, of high repute in speech, clean in actions, orderly in living, 'Reaping the deep-sown furrow of your mind. From which all goodly counsels spring?' Pindar says, 'The vanquished are bound. In the fetters of silence profound,' not absolutely or universally, however, but only those who realize that they are outdone by their enemies in diligence, goodness, magnanimity, kindly deeds, and good works. These are the things which, as Demosthenes puts it, 'retard the tongue, stop the mouth, constrict the throat, and leave one with nothing to say'. 'Be thou unlike the base; this thou canst do'. If you wish to distress the man who hates you, do not revile him as lewd, effeminate, licentious, vulgar, or illiberal, but be a man yourself, show self-control, be truthful, and treat with kindness and justice those who have to deal with you. And if you are led into reviling, remove yourself as far as possible from the things for which you revile him. (Mor. 88B)
\end{abstract}

According to Plutarch, by maintaining a life characterised by virtue and honour, one is able to appropriately respond to one's enemies. These two elements are elaborated on in the rest of the quoted section. Specifically, virtue and beneficial deeds are mentioned, namely by being an 'honest, sensible man and a useful citizen, of high repute in speech, clean in actions, orderly in living'. He further lists 'diligence, goodness, magnanimity, kindly deeds, and good works'. Furthermore, they are to avoid verbal riposte and remain silent. Rather than participate in vice, their virtue should speak, or they should remove themselves from the situation if temptation proves too much. Virtue and beneficial deeds along with wisdom and silence are the elements needed to appropriately and wisely negotiate social conflict and the

24 Plutarch, Mor. 86B-92F. 
hostility of an enemy. In another passage, Plutarch succinctly summarises this strategy:

Men forgo hostility and hate either when convinced that no injustice is being done them, or when they adopt the view that those they hated as evil are good, or thirdly when they have received from them some benefit, 'for the final service,' as Thucydides says, 'though small, if opportunely bestowed, wipes out a greater disservice.' (Mor. 538D)

Plutarch's third strategy here is to provide a benefit for an enemy so as to forgo hostility and hate. This is Plutarch's defence strategy against enemies.

We have all too briefly surveyed the work of some Graeco-Roman moral philosophers and have suggested that good works may refer to beneficial deeds. This may be for the benefit of a group, such as civic benefaction, or it may refer to an individual who benefits. Furthermore, we have noted a somewhat unusual strategy for dealing with enemies, namely good works. The strategy is focused on virtue and benefit. Furthermore, by proving oneself virtuous and beneficial, one may appropriately respond to an enemy and perhaps convert him or her into a friend.

\section{Beneficial Deeds in 1 Peter}

The concept of $\alpha \gamma \alpha \theta$ o $\pi$ oreiv (and cognates) is self-evidently an important feature of the discourse in 1 Peter $(2: 12,14,15,20$;

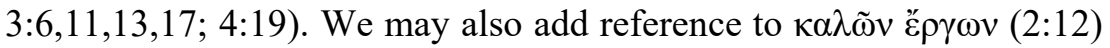
as a conceptual parallel. The consistent use of the concept of 'good works' or that which is 'beneficial' leads Achtemeier to describe 'doing good' as 'virtually a technical term for our author to describe Christians' activity within the pagan world'. ${ }^{25}$ Here I shall provide an overview of 1 Peter's conceptions of good works as beneficial deeds and also interact with various particularities from other proposals.

Selwyn defines the concept of $\alpha \gamma \alpha \theta$ o $\pi$ oteiv broadly as 'active kindness and discharge of social duty' ${ }^{26}$ Scholars have pushed beyond this and questioned whether or not the concept includes civic benefaction or benefaction of a smaller and perhaps more interpersonal

25 Paul Achtemeier, 1 Peter: A Commentary on First Peter (Hermeneia; Minneapolis: Augsburg Fortress, 1996): 185.

26 E. G. Selwyn, The First Epistle of St Peter (London: Macmillan, 1946): 89. 
kind. Bruce Winter has argued that $\alpha \gamma \alpha \theta$ o $\pi$ oté $\omega$ in 2:14 refers to public benefaction. ${ }^{27}$ Winter is not alone in making the connection between this verse and its use of $\dot{\alpha} \gamma \alpha \theta 0 \pi$ or $\dot{\omega} \omega$ (and cognates) to suggest public benefaction. Moffatt spoke of 'law-abiding, good citizens, who were frequently rewarded with crowns, statues, and inscriptions in their honour, by a grateful community'. ${ }^{28}$ Achtemeier suggests understanding $\dot{\alpha} \gamma \alpha \theta 0 \pi$ ot $\dot{\varepsilon} \omega$ as a word drawn from Christian tradition (cf. Luke $6: 33-35 ; 3$ John 11), with the meaning of to do God's will. ${ }^{29}$ At times he seems hesitant to suggest this refers to acts of civic responsibility because it 'would be difficult for Christians of limited means'. ${ }^{30} \mathrm{~A}$ similar view is advocated by Michaels: 'Peter introduces the terminology as if he had in mind works of civic virtue of public benefaction, but his immediate context suggests that the real basis of his language is theological, with roots in the LXX (cf. Ps 33[34]:15-17, cited in 3:11-13) and the Jesus tradition (cf. Luke 6:35). ${ }^{31}$ Williams has argued that the concept of good works be strictly limited to a theological category. Such caution is, however, unpersuasive. Firstly, suggesting that the concept of $\dot{\alpha} \gamma \alpha \theta$ o tradition or the LXX does not negate understanding this concept within the Graeco-Roman matrix among the audiences addressed. It may be that Peter has specifically chosen this term because it relays his understanding that Christians are to benefit others, just as Israel's vocation was to 'seek the welfare of the city' (Jer. 29:7). ${ }^{32}$ Secondly, God's will and the Christological paradigm certainly provide the boundaries for understanding the concept of $\dot{\alpha} \gamma \alpha \theta$ o $\pi$ oté $\omega$ in 1 Peter, but the ubiquitous use of this concept in Graeco-Roman, Jewish, and Christian contexts provides a helpful interpretive matrix, indicating

\footnotetext{
27 Winter, 'The Public Honouring of Christian Benefactors', 87-103.

28 James Moffatt, The General Epistles: James, Peter, and Judas (London: Hodder \& Stoughton, 1963): 122. See also F. W. Beare, The First Epistle of Peter (3rd ed. (Oxford: Blackwell \& Mott, 1970): 142-43; W. C. van Unnik, 'The Teaching of Good Works in 1 Peter', New Testament Studies 1:2 (1954): 92-110; C. Freeman Sleeper, 'Political Responsibility According to 1 Peter', NovT 10 (1968): 282-83; Philip A. Harland, 'Honouring the Emperor or Assailing the Beast: Participation in Civic Life among Associations (Jewish, Christian and Other) in Asia Minor and the Apocalypse of John', JSNT 77 (2000): 99-121, here 115-16.

29 Achtemeier, 1 Peter, 184.

30 Achtemeier, 1 Peter, 184 n.64.

31 J. Ramsey Michaels, 1 Peter (WBC 49; Grand Rapids: Zondervan, 1988): 126.

32 Winter, 'The Public Honouring of Christian Benefactors', 96. Israel's vocation is thus analogous to the vocation of these Christians. Winter is not suggesting a citation of Jer. 29:7.
} 
acts that specifically benefit others. ${ }^{33}$ This is specifically confirmed by Peter's use of other terms with a similar meaning, namely $\kappa \alpha \lambda \tilde{\omega} v$

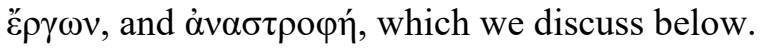

\subsection{Peter 3:10-12}

We begin with 1 Peter $3: 10-12$ because this is the clearest clue to Peter's use of the good works motif in his strategy. 1 Peter 3:10-12 forms part of a quotation from Psalm 33:13-17 LXX. Here, our author justifies the instruction to do good by an appeal to the Scriptures that shaped these Christian communities. Scholars are right to note the importance of this Psalm in the theology of 1 Peter. ${ }^{34}$ There is little doubt therefore that this Psalm plays an important role in determining the language and concepts of 1 Peter and thus it affects our understanding of the strategy of 1 Peter. Williams seizes this insight to state that 'If the good works motif is grounded in and flows out of the Hebrew Scriptures, then we should be hesitant about too quickly connecting the theme with Hellenistic social norms. ${ }^{35}$ However, this proves to be a false dichotomy. The question that needs to be addressed is since Peter draws on both Jewish and Hellenistic topoi, how is the concept of good works understood within both categories, and is there overlap between these two? Williams agrees that there is overlap in 1 Peter between Graeco-Roman conceptions of good works and 1 Peter's understanding. ${ }^{36}$ Furthermore, it is demonstrated above that Jewish conception of good works, understood as beneficial deeds, do overlap with certain Hellenistic conceptions of good works. Thus, there is no need to posit opposition here. Clearly, the motivation and framework within which these beneficial deeds are understood will be different. But concerning the actual deeds there is significant overlap. Furthermore, Williams has not properly addressed the context and specific elements of 3:10-12, which I suggest directly undermines his proposal that good works be understood as subversive practices. A closer look at this passage reveals several significant elements that support my thesis.

\footnotetext{
33 Van Unnik, 'Teaching of Good Works', 96f.

34 See Jacomien Zwemstra and Elma M. Cornelius, 'Die kommunikatiewe funksie(s) van die gebruik van Psalm 34 in 1 Petrus', Acta Patristica et Byzantina 14 (2003): 32544.

35 Williams, Good Works in 1 Peter, 249.

36 Williams, Good Works in 1 Peter, 257.
} 
It is important to note at the outset that this instruction (3:10-12) does not merely pertain to intra-communal relationships but specifically relates to how these Christians are to engage with outsiders. $^{37}$ This is evident from 3:9 and 3:13-17, which deal with Christian responses to outsiders, but also from 3:1-6, which deals with Christian wives and pagan husbands, and 3:8, which need not be exclusively related to internal relationships. ${ }^{38}$ Also, 1 Peter 3:10-12 forms an inclusio with 2:12, with a central theme being the performance of good amidst outsider hostility. Then we must note that the rationale for non-retaliation in 3:9 is given through an appeal to the scriptures in 3:10-12. This is indicated by the opening yó $\rho$ in 3:10 (cf. $2: 25$ with the reference to Isa.53:6), ${ }^{39}$ which can either indicate a reason, clarification, or inference. ${ }^{40}$ Levinsohn states that 'The presence of $\gamma$ á $\rho$ constrains the material that it introduces to be interpreted as strengthening some aspect of the previous assertion, rather than as distinctive information.' ${ }^{41}$ This connects $3: 10-12$ specifically to the instruction of 3:9. 1 Peter 3:10-12 provides more specific information regarding their response to hostile outsiders. These Anatolian Christians are not to participate in verbal riposte with those who maliciously slander them. Given the socio-historical context faced by these Christians and the emphasis in 1 Peter on slander and malicious speech, the temptation for them to respond maliciously would have been significant. Furthermore, speech ethics are important to both Jewish and Graeco-Roman moral philosophers, thus, the context of 3:10-12 is predominantly that of Christian interactions with outsiders. This instruction therefore forms an important contribution to Peter's strategy for negotiating life in the Graeco-Roman world.

37 Leonhard Goppelt, A Commentary on 1 Peter (Grand Rapids: Eerdmans, 1993): 228; Achtemeier, 1 Peter, 225; J. H. Elliott, 'Disgraced Yet Graced: The Gospel According to 1 Peter in the Key of Honor and Shame', BTB 24 (1994): 166-78, here, 171.

38 Winter, Seek the Welfare of the City, 21.

391 Peter employs various markers that introduce quotations from the Jewish

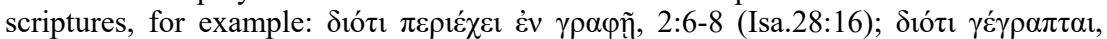

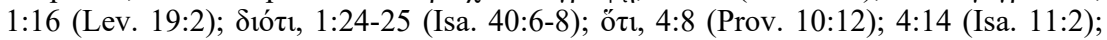
5:5 (Prov. 3:34); каí, 4:18 (Prov. 11:31).

40 BDAG \#1599.

41 Stephen H. Levinsohn, Discourse Features of New Testament Greek: A Coursebook on the Information Structure of New Testament Greek (2nd edn; Dallas: SIL International, 2000): 91. 
The strategy presented in 3:10-12 has both negative and positive components. Firstly, they are to refrain from invective or deceitful speech (Ps. 33:14 LXX) and turn away from all evil activities (Ps. 33:15 LXX). Positively, they are to perform d $\gamma \alpha \theta$ ó $\varsigma$ and seek/pursue

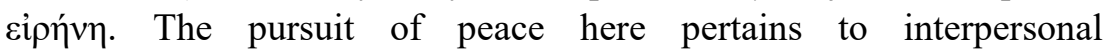
relationships. ${ }^{42}$ Given that the context is interaction with hostile

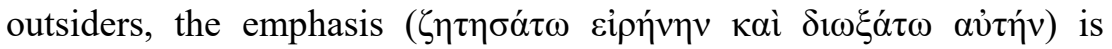
needed to remind these Christians that as much as they might desire retaliation and revenge they are to vigorously pursue peaceful relationships with the pagans they are associated with (e.g. 2:18;3:1) and others in their extended networks.

It is within this context of non-retaliation and seeking peace with outsiders that we have the instructions to perform $\alpha \gamma \alpha \theta$ óc. Doing good is thus a means to creating peace between hostile groups, as is nonretaliation and blessing. If this understanding is correct, we have several reasons to object to Williams' reading of good works as subversive resistance. If Williams is right, how does this aid Peter's instruction that they seek peace with outsiders? How does subversive resistance not equate to retaliation, but with different 'weapons'? 1 Peter 3:10-12 is set within the context of an instruction to not retaliate (3:9) and the rhetorical question of who will harm them for doing $\dot{\alpha} \gamma \alpha \theta$ ó $\varsigma$ (3:13). The goal of 3:10-12 is for these readers to have 'life' and 'good days' (3:10) and 'peace' with others (3:11). I propose therefore that Peter's strategy to attain this is, firstly, by avoiding both invective speech and evil activities that would likely cause harm or make matters worse. Secondly, and positively, it is the pursuit of peace through activities that promote peace, which specifically includes good works. Good works are thus seen as the means by which these Anatolian Christians will foster peaceful relationships with others. Once this is recognised, the remainder of our investigation is to note the specifics of what good works consist of and how this is used in 1 Peter.

\subsection{Peter 2:12}

There are four reasons to see 1 Peter 2:12 as pertaining to mission and ethics. Firstly, it explains the relationship between 2:9-10 and 2:12.

42 Mark Dubis, 1 Peter (Waco, Texas: Baylor University Press, 2010): 102. See also Matt. 5:9; Rom. 12:18; 14:19; 2 Cor. 13:11. 
Secondly, it forms a parallel with $3: 1-2$, which is undoubtedly

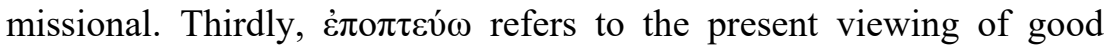
works, not a viewing on judgement day, and, lastly, that in 1 Peter Christians glorify God not pagans. If 2:12 reflects the Jesus tradition of Matthew 5:16, this offers further confirmation of a connection between mission and ethics. Therefore the internal and external evidence favours understanding 2:12 as describing a relationship between mission and ethics, where praxis forms an important element of proclamation. The question before us now relates to the content of the 'honourable deeds' mentioned in 2:12.

1 Peter 2:12 employs two specific terms that are at home within a Graeco-Roman context. First, $\alpha v \alpha \sigma \tau \rho o \varphi \eta ́$, about which Spicq writes

It used to be claimed that the moral and religious meanings derived from the OT, but they are attested in the secular literature, in the papyri, and especially by epigraphy, notably in the honorific decrees that give particular honour to magistrates and functionaries whose conduct has been irreproachable. ${ }^{43}$

Thus $\dot{\alpha} v \alpha \sigma \tau \rho \circ \varphi \eta$ refers to conduct that is seen as virtuous and/or beneficial and describes those who are exemplary in some way.

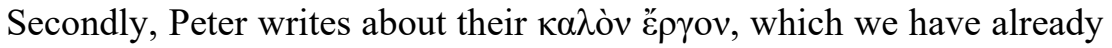
noted describes activity that is honourable and beneficial. This view is confirmed when we see it in contrast to каколоเós, which pertains to 'doing evil,' or performing some 'detrimental act'. ${ }^{44}$ Holloway suggests that каколою́ $\varsigma$ be understood as referring to criminal activity, or malus homo. ${ }^{45}$ Whether or not this refers specifically to criminal activity or just activity that is socially subversive or unacceptable, for our purposes the point remains that this refers to activity that does not benefit others but rather does harm to others. Therefore, the contrast

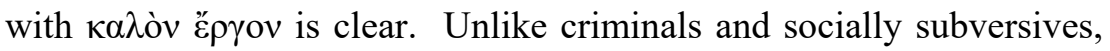
those with honourable character and conduct are those who live virtuously and are beneficial members of society. Achtemeier rightly notes that

43 Ceslas Spicq, Theological Lexicon of the New Testament (Peabody, Massachusetts: Hendrickson, 1994), 1: 112-13.

44 BDAG \#3877. Каколоı̀̀ $3: 9,10,11,12,17 ; 4: 15)$.

45 Paul A. Holloway, Coping with Prejudice: 1 Peter in Social-Psychological Perspective (Tübingen: Mohr Siebeck, 2009): 177. Holloway does this in part because of the association of these Christians with other criminal activity in 4:15. Elliott, 1 Peter, 794 disagrees that this refers to criminal activity. 
the choice of $\kappa \alpha \lambda$ ó ('good') here links Christian ethics to the best of pagan culture to show that Christians are not a threat by reason of their standard of conduct. The exhortations that follow in 2:13-3:7 are examples of the good works Christians are to do in the midst of their culture to avoid unnecessary offense to their unbelieving contemporaries. ${ }^{46}$

I therefore suggest that 2:13-3:7 are illustrative of the kinds of good works these Christians are called to. ${ }^{47}$

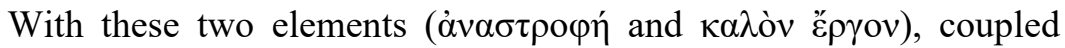
with the knowledge that Peter has employed a Graeco-Roman form, namely the Haustafel, to instruct these Christians, we may propose that the primary setting within which to understand these terms is that of Graeco-Roman moral discourse. With this in mind, we note that this assumes an overlap in conceptions between Christians and GraecoRoman moral philosophy of what is considered honourable conduct that benefits others. ${ }^{48}$ This is confirmed by Peter's statement that

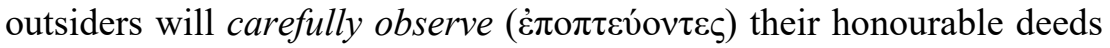
and glorify God. Of course, an overlap in areas of morality does not indicate their moral visions are identical in all aspects (cf. 1:18; 2:21; $4: 3){ }^{49}$

Sandnes insightfully notes that "The topic of "doing good" forms an inclusio to this code, manifested in 2:11-12 and in the lengthy

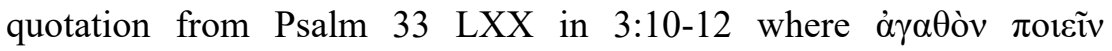
appears. ${ }^{50}$ What this inclusio suggests is that the duties of the

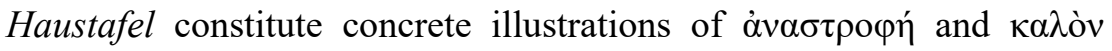
Épyov which these Christians are exhorted to perform. Concrete examples of honourable conduct are found throughout the Haustafel: being dutiful to a) those in authority, including governors and the emperor (2:13-14,17); b) masters, even those who are morally corrupt $(2: 18)$; c) husbands, even those who are hostile to the gospel (3:1); and d) those who slander or abuse Christians (3:9; cf. 4:16). The

\footnotetext{
46 Achtemeier, 1 Peter, 177.

47 So also D. F. Watson and T. Callan, First and Second Peter (Paideia; Grand Rapids: Baker, 2012): 59.

48 Achtemeier, 1 Peter, 176 makes this claim based on the use of $\dot{\alpha} v \alpha \sigma \tau \rho \circ \varphi \eta$.

49 Achtemeier, 1 Peter, 176 n.58.

50 K.-O. Sandnes, 'Revised Conventions in Early Christian Paraenesis' in James Starr and Troels Engberg-Pedersen, eds, Early Christian Paraenesis in Context (BZNW 125; Berlin: De Gruyter, 2004): 385, cf. 387, where Sandnes again states 'The inclusio has demonstrated that the entire household code spells out what the paraenesis to perform good is all about.'
} 


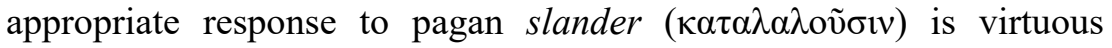
conduct that benefits others (cf. 3:9-12). Hostility due to Christian devotion provides the appropriate context of honourable conduct and works that benefit those who antagonise these Christians. If 2:12 is understood as a reference to honourable deeds that will aid the conversion of outsiders, then we cannot understand these honourable deeds as referring to subversive activities, as Williams suggests. Rather, we must view these deeds as beneficial activity that will hopefully aid the mission of these Christians.

\subsection{Peter 2:14}

An important piece of evidence for understanding good works comes from 1 Peter 2:14, which states that authorities are to 'punish those who do wrong and praise ('̌ $\pi \alpha i v o v)$ those who $\alpha \gamma \alpha \theta$ o $\pi$ ol $\tilde{v} v$ ' (2:14). The political context $(2: 13-14)$ in which we find $\alpha \gamma \alpha \theta$ o $\pi$ or $\varepsilon \omega$ provides the contextual clue to its referent. ${ }^{51}$ In the light of this, we should recall Xenophon's words that

in well-ordered cities the citizens are not satisfied with passing good laws: they go further, and choose guardians of the laws, who act as

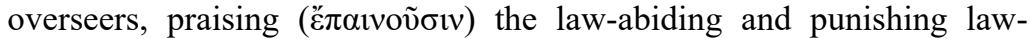
breakers. So I charged my wife to consider herself guardian of the laws to our household. ${ }^{52}$

It thus clear that Peter has picked up on a common topos concerning the administration of governmental authorities. ${ }^{53}$ If taken as a reference to Christian morality, this raises the question 'How would the authorities know of the good morals of its Christian citizens in the cities mentioned in the provinces of Asia Minor in 1 Peter (Pontus, Galatia, Cappadocia, Asia and Bithynia)?'54

Achtemeier sees the role of the governing authorities as those who may provide protection to the Christians, because of their performance of good deeds, from those who would seek to harm them in unlawful ways. ${ }^{55}$ While this makes sense of the first part of 2:14, which speaks of the role of governing authorities as those sent to punish those who

51 Winter, 'Public Honouring of Christian Benefactors', 93.

52 Xen. Oec 9.19.

53 Also noted by Williams, Good Works in 1 Peter, 176. Williams fails to note the particularities of this passage and how it forms a striking parallel to 1 Pet. 2:14-15.

54 Winter, 'Public Honouring of Christian Benefactors', 93.

55 Achtemeier, 1 Peter, 184. 
do evil, we must question how this makes sense of the second part, which speaks of civic authorities 'praising (Ë $\pi \alpha$ wvov) those who perform good deeds' (2:14). While Achtemeier is surely correct to note the hope of protection from such authorities, his position does not take into account the rhetorical effect of the hope that those same authorities would commend acts that benefit the community in some significant way. Achtemeier states that 'the author assumes that such acts of political loyalty will also gain positive acknowledgement from unbelievers as well. ${ }^{56}$

If this is the case, we must ask what could these Christians have done to warrant positive public acknowledgement? Other than benefaction, what other category presents itself for our understanding in this passage? But, if we see this as a reference to beneficial deeds and not just limited to political loyalty, Peter's strategy becomes clearer. Peter's use of $\dot{\alpha} \gamma \alpha \theta 0 \pi$ oté $\omega$ in this context demands an understanding of some act that benefits people to the extent that pagan authorities take note of such activity and are impressed by it. ${ }^{57}$ While it certainly could refer to 'people who do something deserving a special distinction', ${ }^{58}$ it certainly entails acting virtuously in the home and benefitting those in the household. Thus, the point of this passage in 1 Peter is that the discharge of household duties benefits the flourishing of the city, and households that undermine the city could incur the judgement of governing authorities, while households that embody virtue could incite the praise of those in authority. Describing the function of 'doing good' in 1 Peter, van Unnik states that

The interesting thing is that human authorities are supposed to recognise what is "well-doing", and that a general rule of a state towards its citizens is meant, which must be - according to the will of God - an incitement for the Christians to live up to this standard of first-class citizens in order to stop slander. ${ }^{59}$

Peter is here urging his audiences to engage in a similar way as others in society who act for the wellbeing and benefit of others. Judge,

\footnotetext{
56 Achtemeier, 1 Peter, 185.

57 Achtemeier, 1 Peter, 185 is right to note that this 'is not to say our author thinks all Christian activity gains such acknowledgement; there are necessary Christian acts that will stir hostility (e.g. 3:14, 17; 4:3-4)'. But this does not negate the idea that at least some actions overlap with conceptions of what is beneficial and will incite the praise of pagans.

58 Van Unnik, 'Teaching of Good Works', 99.

59 Van Unnik, 'Teaching of Good Works', 99.
} 
speaking of 1 Peter's audience, writes that 'nothing must be done that would upset the government' ${ }^{60}$ Thus, we suggest that Peter extends the hope that various authorities might take note of various 'good' acts performed by the Christians $(2: 12-15 ; 3: 13-16) .{ }^{61}$ This is wider than the view of Balch, who suggests that the governing authorities would praise Christians specifically for obedience to the household codes. ${ }^{62}$ It may include this, but it cannot be limited to it. Furthermore, Peter does not speak of obedience as the reason for praise, but rather deeds that benefit others. Obedience in 1 Peter is primarily to the Father $(1: 14)$ and to the truth $(1: 22)$. With regards to their strategy for relating to outsiders, the contrast in 1 Peter is between beneficial works $(2: 14,15,20 ; 3: 6,11,13,17 ; 4: 19)$ and harmful works $(2: 12,14 ; 4: 15$; $3: 17)$. But what purpose does this information play in Peter's strategy for these Christians? 2:14 is located within the Haustafel, which suggests that this exhortation must be related to duties of those Christians who belong to various households. 'The doing of public good in vv. 14-15 is but one example of the theme from 2:12-3:6, where "doing good" in the context of less than easy circumstances is seen as the means of establishing Christian credibility in social relationships as well as in the political sphere. ${ }^{63}$ This is confirmed by the next verse, 2:15.

\subsection{Peter 2:15}

In 2:15 we have an element of Peter's strategy revealed. The purpose

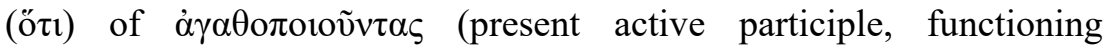
instrumentally ${ }^{64}$ ) is that it appropriately responds to those who lack discernment (ö $\varphi \rho \omega v)$ concerning Christ and their devotion to him. If these Christians were suspected of pernicious and insidious behaviour $(2: 12,14 ; 4: 15)$, performing deeds that benefit others would be a decisive refutation of such a mistaken assessment, and could

60 E. A. Judge, Social Distinctives of the Christians in the First Century: Pivotal Essays (Grand Rapids: Baker Academic, 2008): 54.

61 Van Unnik, 'The Teaching of Good Works', 107 speaks of Christians not retreating but living within the given conditions with good works extended to those not belonging to the Christian group. He goes on to note that "No special "Christian", but truly human ethics are demanded.'

62 David Balch, Let Wives Be Submissive: The Domestic Code in I Peter (Chico, California: Scholars Press, 1981): 94.

63 Winter, 'Public Honouring of Christian Benefactors', 94-95.

64 Achtemeier, 1 Peter, 185; Michaels, 1 Peter, 127. 
potentially alleviate the current wave of slander experienced by these Christians. ${ }^{65}$

It is also important to note the commonality of perspective between Christians and pagans on what constitutes $\tau$ ò $\alpha$ jo $\alpha$ óv. ${ }^{66}$ For outsiders to praise the activity of Christians as $\tau$ ò $\dot{\alpha} \gamma \alpha \theta$ óv indicates that there must

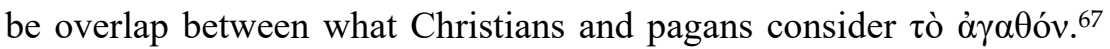
This overlap gives us further insight into what constitutes the 'good works' which are discussed in the rest of this discourse. This fits with what we have argued regarding 2:12. We may further note the general vice list of 4:15 as another example of overlapping moral visions between these Christians and outsiders. Of course, an overlap indicates that there are elements that are both common and different. Peter's conception of good works will be filled and shaped by God's will along with other elements of a specifically Christian ethic (e.g. love for one's enemies). But the overlap can be strategically beneficial to these Christians as they negotiate the complexities of life in the GraecoRoman world. Thus Achtemeier notes that 'the good and decent lives of the Christians will, our author is convinced, help overcome the hostility based on ignorance that they faced in their contemporary society'. ${ }^{69}$

In contrast to this reading, Williams has offered, to my knowledge, a novel interpretation of this verse. He suggests that 2:15 be understood with regards to eschatological vindication. Williams notes that 'The key question upon which the interpretation of this verse hinges is, when and how would the silencing of detractors take place?' ${ }^{70} \mathrm{He}$ proposes that this silencing be understood eschatologically, 'together with the glorifying referred to in $2: 12^{\prime} \cdot{ }^{71}$

65 Steven Richard Bechtler, Following in His Steps: Suffering, Community, and Christology in 1 Peter (Atlanta: Scholars Press, 1998): 162 therefore notes that benefaction 'is the only course of action God has willed the addressees to pursue in order to silence their accusers'.

66 Williams, Good Works in 1 Peter, 257-60 acknowledges the overlap, but does not recognise how it undermines his thesis.

67 Achtemeier, 1 Peter, 184; Lewis R. Donelson, I and II Peter and Jude (Louisville, Kentucky: Westminster John Knox, 2010): 93; Karen H. Jobes, 1 Peter (Grand Rapids: Baker, 2005): 175; Michaels, 1 Peter, 117.

69 Achtemeier, 1 Peter, 185.

70 Williams, Good Works in 1 Peter, 179.

71 Williams, Good Works in 1 Peter, 179. 
Rather than admonishing his readers with an optimistic and apologetic strategy of good works, the author of 1 Peter is resigned to the reality of the present conflict. But even though the good deeds of Christians might not assuage the antagonism of their detractors, ultimately the unbelieving world will recognise its error on the day of God's judgement. Moreover, what this means for the present discussion is that this verse cannot be used to support the notion that doing good in 1 Peter involved commendable social practices ... What this means is that the author's admonition to 'do good' is not viewed as a remedy for the present conflict but a future indictment against unbelievers. ${ }^{72}$

The theme of the eschatological vindication of these Christians is clearly part of Peter's strategy to console them in their time of tribulation $(3: 17-22 ; 4: 17-19 ; 5: 10) .{ }^{73}$ The question here is whether this is the best way to understand 2:15. 2:13-17 provides a coherent unit of thought where eschatology is nowhere explicitly mentioned. While 2:12 may rightfully be understood as referring to the eschatological salvation of outsiders, it seems strained to suggest an eschatological setting is what Peter is referring to in 2:15. Williams is of course right to note that 'good works are no guarantee that the hostility will end'. ${ }^{74}$ But that does not entail a rejection of the hope that good works may provide an opportunity for dialogue (3:15-16) or even lead to conversion (3:1-2). Williams states that 'there are no other instances in the epistle where detractors approvingly acknowledge the behaviour of Christians without being converted'. ${ }^{75}$ But this assumes more than it demonstrates. Given the Graeco-Roman strategy that good works are a means to alleviate hostility and perhaps win a friend(s), our author may rightly be hopeful that such a strategy of beneficial deeds would alleviate the vicious slander currently experienced by these Christians. Furthermore, Elliott is right to note that 'By doing what is right Christians will not only silence their detractors ... they will also be assuring outsiders that Christians share with their neighbours an earnest concern for proper and honourable conduct. ${ }^{76}$ This coheres well with what we have noted concerning 3:10-12 and the goal of pursuing peace with outsiders.

72 Williams, Good Works in 1 Peter, 174, 180.

73 Holloway, Coping with Prejudice, 207-208.

74 Williams, Good Works in 1 Peter, 180.

75 Williams, Good Works in 1 Peter, 179-80.

76 Elliott, 1 Peter, 495. 


\subsection{Peter 2:20}

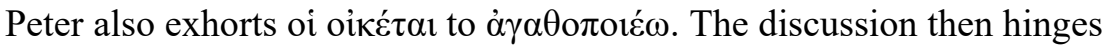
on how we understand benefaction. Furthermore, if we recall Seneca's discussion that slaves can benefit their masters, we must admit that Peter may have appropriated the language of benefaction so that what these household slaves are exhorted to is not the erecting of buildings or other outlandish examples of civic benefaction. ${ }^{77}$ Rather, Peter exhorts them to perform exemplary duty and virtue towards masters which may have included simple acts of public benefaction such as erecting a public inscription or going beyond the boundaries of their duty to perform some act of virtuous beneficence. ${ }^{78}$

Williams appeals to this text as an example where 'good works will cause further conflict rather than solve it' ${ }^{79}$ Williams asks 'If some overlap between Christian and "pagan" standards does exist, then why would the author expect them to be met with hostility rather than acceptance?' ${ }^{80}$ It should be noted, firstly, that Williams admits an overlap between Christian and pagan conceptions of good works. ${ }^{81}$ Secondly, Williams admits there may be a variety of reasons why deeds which are usually deemed honourable by pagan society are deemed evil and malicious. For example, they may have misinterpreted these deeds. ${ }^{82}$ Thirdly, outsiders may have accurately perceived that the intention of these works is to reduce hostility or to seek their conversion. Fourthly, specific good works that, according to 1 Peter, do not overlap with Graeco-Roman concepts, might be the cause for hostility. Fifthly, despite their good works, these Christians are still

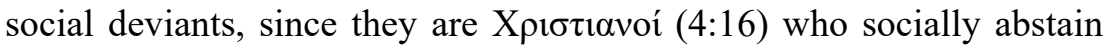
from cultic practices and deny worship to the plethora of GraecoRoman gods (4:3-4). To use language that was later used to describe Christians, but which is equally valid for these Anatolian Christians,

\footnotetext{
77 See Williams, Good Works in 1 Peter, 85.

78 See P. H. Towner, 'Can Slaves Be Their Masters' Benefactors? 1 Timothy 6:1-2a in Literary, Cultural and Theological Context', Current Trends in Scripture Translation 182/183 (1997): 39-52.

79 Williams, Good Works in 1 Peter, 179 (cf. 82, 173, 180, 255).

80 Williams, Good Works in 1 Peter, 258.

81 See Williams, Good Works in 1 Peter, 257-60.

82 Williams, Good Works in 1 Peter, 258. Christian deeds were often misinterpreted by their pagan contemporaries. See accusations of incest, cannibalism, and infanticide (cf. Justin, 1 Apol. 26.7; 2 Apol. 12; Tatian, Or. 25; Minucius Felix, Oct. 9; Eusebius, H.E. 5.1.14).
} 
they were atheists, those who denied worship to other gods. ${ }^{83}$ Thus, there is no need to radically alter our conception of good works from beneficial deeds to predominantly subversive activities. Finally, there is no need to suggest that every good work would cause hostility from outsiders. Good works may be the cause of a variety of responses from outsiders.

\subsection{Peter 3:6}

1 Peter 3:1-6 presents the situation of Christian wives married to pagan husbands. This example is used because it is indicative of the wider situation that almost all Christians in Anatolia are currently facing: a vulnerable existence in positions where they have little or no power. Peter's instruction is that wives engage in an ethical-apologetic in the hopes that this will convert their husbands. The specific ethic espoused is one of duty and obligation to one's own husband (3:1) as well as through conformity to socially acceptable forms of dress and demeanour (3:3). Furthermore, this also includes a call to perform good deeds (3:6). These three elements of 1) duty, 2) social conformity, and 3) good works comprise key elements in Peter's strategy for Christian interaction with pagans. The key word used to describe these three elements throughout 1 Peter is 'conduct' ( $\alpha \alpha \sigma \tau \rho o \varphi \eta$ ), a word with rich associations in Graeco-Roman society and moral philosophy.

Peter's instructions to wives, predominantly of pagan husbands, indicate that 'doing good' is a vital component of their complex negotiation of devotion to Jesus and duty to one's own husband. As in 2:12, we have Peter stressing their $\dot{\alpha} v \alpha \sigma \tau \rho o \varphi \eta ́$ and also their $\dot{\alpha} \gamma v$ ó $\varsigma$ (3:1-2). The immediate context of this discussion concerns women's fashion and conduct (3:3-4). To put this episode into context, Xenophon provides a helpful window into the ancient household and the duties of a wife. Xenophon recounts the story (Oec. 9.11-13) of hiring a housekeeper and the various duties and character traits she has. In this context, there is an important discussion of the role of the wife (Oec. 9.14-15), who must be dutiful and responsible for the household, and those within it. Xenophon then describes this wife as $\dot{\alpha} \gamma \alpha \theta \tilde{\omega} v(O e c$. 9.19). By discharging her duties concerning the household, this wife is described as one who benefits the husband and one who is a model

83 See Justin Martyr, Apol. 1.5-6; Tertullian, Apol. 10.1; 40.2; Mart. Pol. 12.2; Lucian, Alex. 38; Apuleius, Met. 9.14; Eusebius, H.E. 4.13; Origen, Comm. Matt. 24.9. 


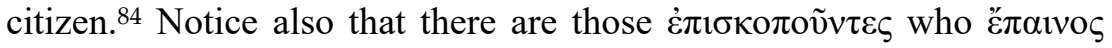
those who are law abiding and punish those who are not, an idea encountered in 1 Peter 2:14. Peter instructs these wives, like Sarah (3:6), to continue to benefit ( $\dot{\alpha} \gamma \alpha \theta$ o $\pi$ otoṽ $\sigma \alpha)$ husbands and those associated with the household with conduct that is honourable and exemplary. By doing good, a wife will bring honour to the household and her husband and avoid negative stereotypes of those who dress inappropriately, and, by implication, engage in shameful activity. These wives are to act in a manner that is praiseworthy, especially since their devotion to Jesus will cause tension in households. ${ }^{85}$ These Christian wives are to be those who benefit the household and their own husbands, and thus conduct themselves honourably. ${ }^{86}$ By embracing this strategy they will potentially alleviate their own suffering and aid them to alleviate ignorance and convert pagans. ${ }^{87}$

\section{Peter's Strategy}

We may conclude the following concerning Peter's strategy. Firstly, the author of 1 Peter sought to communicate in a manner that would have been readily understood by his predominantly Gentile audience. Acculturation in 1 Peter serves a pedagogical function. Secondly, the tension caused by their conversion and the questions that subsequently arose concerning the specifics of holiness would have become acute in these trying circumstances. Thus, while Peter's exhortations are directly addressed to Christians, they nevertheless consistently involve Christian interaction with pagan outsiders in civic (2:12-17) and domestic spheres $(2: 18-20 ; 3: 1-7)$. These instructions to vulnerable Christians become paradigmatic for other Christians in their various relationships with outsiders. Then Peter's acculturation and accommodation of aspects of Graeco-Roman moral philosophy clearly demonstrates an author who has chosen to focus on particular aspects

84 Xenophon (Mem. 2.2.13) describes those who treat their parents appropriately as

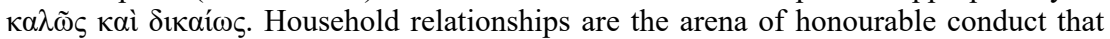
will either invite shame or honour from those associated with the household.

85 Donald Senior, 'The Conduct of Christians in the World (2:11-3:12)', Review Expositor 79 (1982): 427-33, 435.

86 Achtemeier, 1 Peter, 216.

87 Holloway, Coping with Prejudice, 190 suggests doing good is not some general ethical imperative, but an ethic constructed precisely to refute the anti-Christian stereotyping confronting the readers of 1 Peter'. 
of Christianity that cohere well with the dominant society. Of course, Peter's critique of various aspects of society suggests this is not a wholescale mimicry of Graeco-Roman morality, but rather a nuanced exhortation providing instructions concerning the overlap of thinking and morality, and the necessary rejection and avoidance of certain features that are inconsistent with their theology and values. A focus on the overlapping elements of the Graeco-Roman world and Peter's vision of Christianity should reduce tension and provide opportunities for clarification and communication regarding the devotion of these Christians. This further aids the missional strategy and hope that they too will be rescued and 'won over'. Thus once again we see an author concerned with education and exhortation, seeking to aid these communities as they negotiate the complexities of life in the GraecoRoman world as Christians.

The strategy of 1 Peter is to carefully negotiate life in the GraecoRoman world. By negotiating social conflict through non-retaliation and various positive actions towards outsiders it is hoped that this would alleviate their current predicament of suffering and hostility. The strategy of negotiating conflict by avoiding retaliation and the performance of good toward one's enemies is similar to that found in Graeco-Roman sources. This includes practising a variety of virtuous deeds, discharging social duties, and acting in ways that benefit others. After a period of time, by outsiders carefully observing the life of these Christians, it is hoped that such a strategy would evoke curiosity from outsiders and lead to various situations where Christians are able to gently and respectfully defend their devotion to Jesus and their way of life (3:15-16). By doing so it is further hoped that such a strategy would alleviate outsiders' ignorance and perhaps lessen Christian suffering. The ultimate goal of this strategy is the conversion of outsiders $(3: 1-2 ; 2: 12)$. 